\title{
The Many Faces of Mentor-Mentee Relationships in a Pre-Service Teacher Education Programme
}

\author{
Shosh Leshem \\ Oranim Academic College of Education, Tivon, Israel \\ Email: Shosh-l@zahav.net.il
}

Received May $5^{\text {th }}$, 2012; revised June $10^{\text {th }}, 2012$; accepted June $20^{\text {th }}, 2012$

\begin{abstract}
Different schools of thoughts concerning the conceptualization of the role of the mentor point at different dimensions within the role. It is suggested that assumptions and beliefs about the nature of teaching and learning provide the rationale for the mentors' approaches. The notion of idiosyncrasy of mentoring and the complexity of the mentor-mentee relationship has challenged the study of 15 pairs of student teachers and their mentors' perceptions on the role of the mentor. The study also identifies types of relationships that transpire within pairs. The study was conducted in a pre-service teachers' programme in a teacher education college in Israel. Findings indicate that there is no great dispute between mentors and mentees on the mentoring role. However, the types of relationships that have been identified highlight the complexities that mentorship entails and arouse critical questions concerning the benefits of the mentoring process. It has been concluded that mentoring is a dynamic non-linear process which requires mentors and mentees to adapt to contextual situations. It is suggested that more attention must be given to preparing students and mentors for their roles in the practicum.
\end{abstract}

Keywords: Mentoring Relationships; Practicum; Teacher Education

\section{Introduction}

\section{The Complexity of Student-Mentor Relationship}

The mentoring process in the practicum of student teachers constitutes a critical factor in their professional development. Student teachers view the process in their practice teaching as the best way to acquire professional knowledge and competence as a teacher (Hascher, Cocard, \& Moser, 2004; He, 2010). It also serves as a protected opportunity for experimentation and socialization within the profession (Hascher et al., 2010). Hawkey (1997) contends that mentoring is idiosyncratic in the sense that mentors and student teachers bring into the mentoring process a diversity of beliefs and concerns that lead to complex interactions and complicated dynamics. Wang (2001) extends this view and indicates that the different perceptions can affect the relationship and the learning process that develops for both mentor and student by influencing how they communicate and what advice is given. In the same vein, different conceptualizations of teaching imply different views of the processes of learning to teach and a different vision of the role of the mentor (Maynard \& Furlong, 1993). Young et al. (2005) conclude that mentoring could be seen as perplexing and challenging due to contradictions in the way it is described by different mentoring studies and the actors involved in the mentoring process. In a recent study analyzing mentors' needs from 12 European countries the data reflect a high range of perspectives partly due to the diversity of educational systems in which they are embedded (Jones, 2009). The idiosyncrasy of mentoring and the fact that no generalizations can be made, might lead practitioners to the conclusion that “anything goes” (Cain, 2009). This mind-set might affect the quality of mentoring.

Maynard and Furlong further maintain that personal factors have an influence on the formation of students' concepts, beliefs and expectations about the nature of teaching and learning. If the role of the teacher may be viewed as "inappropriate" or "simplistic", then, they argue, they will need a mentor to "guide their seeing" so that they may adjust or redefine their concepts. However, mentors themselves bring their own perspective to bear in their work as mentors. According to Elliot and Calderhead (1993: p. 179) "assumptions about the very nature of teaching and how learning occurs provide part of the rationale for the mentors' approaches". They claim that having predetermined conceptions about the mentoring role would affect the way they enact it. It is also suggested that mentoring is a contextualized practice shaped by culture, curriculum, and teaching organization (Hiebert, Gallimore, \& Stigler 2002; Jones, 2009). Furthermore, some student teachers report on negative experiences when they perceive their mentor as having dissimilar attitudes beliefs and values from their own (Eby et al., 2000). It is suggested therefore that mentors need to be informed about the needs of their mentees in order to establish an effective mentoring relationship (Iancu-Haddad \& Oplatka, 2009). Russell and Russell (2011) quoting Tauer (2002) support this notion and state that the most successful mentoring relationships are based on shared values, goals and understandings and in order to understand the dynamics of mentoring, it is useful to gain the mentor's perspective on the mentoring relationship. Thus the perceptual gaps under which mentoring and learning to teach take place are complex.

The impetus for this study emerged out of mixed voices of student teachers in a teacher education college, who expressed their concerns in random meetings that I had with them about their experiences in the mentoring process.

Two of these voices are Lisa and Iris who were in their second year of practice teaching, each in a secondary school context.

Lisa's voice: 
Feedback is very important but we need to speak the "same language", I mean, we should have similar beliefs to avoid conflicts. We had disagreements concerning the lessons that I taught. She did not accept my views which were against hers. I personally think pupils should be exposed to contradictory views, they should know everything and not only things that are in line with the teacher's beliefs. I will teach differently when I become a teacher but we agreed not to get into conflicts over it.

Lisa believes that the mentor student relationship should be strongly based on "similar beliefs" in order to avoid conflicts. Lisa articulates her own beliefs about how pupils should be taught however, she sought to avoid confrontation. Lisa describes a relationship of compliance.

Iris's voice:

I first had a different mentor who did not challenge me at all. She accepted almost everything I said or did. I asked to be transferred to another cooperating teacher. This is not what I was looking for.

In Iris's case, they did "speak the same language" and there was no conflict. Yet, Iris was looking for more "action”. For Iris, "seeing eye to eye” was not a challenge and did not enhance her learning.

What might be implied in Iris's and Lisa's experiences is the perceptual gaps that Eby (2000) and later Russell (2011) have identified. The words from these two student teachers reflect their direct encounters with the mentoring process in the practicum. Being involved in the practicum programme at the college and knowing that these experiences were recurrent, raised critical questions for me about role perceptions and mentor-mentee relationships.

Thus the questions that the study sought to answer are:

1) What do mentors think of their role and what do students think of the mentor's role? Do they have similar or different perceptions?

2) What sort of relationships can be identified between the mentor and the student?

The assumption was that gaining more insights on these issues would help to facilitate the mentoring experience of student teachers and their mentors in the practicum.

\section{Role Perceptions}

Handy (1999) contends that role ambiguity results when there is uncertainty in the minds of the focal person or of the members of the role set of what their role is at a certain given time. In the same vein, role conflict or role incompatibility results from a clash between other people's expectations of one in one's role and one's own self-concept. He argues that this feeling is not necessarily bad as the ability to shape one's own role is a freedom that many people desire, but it may lead to role stress.

Although mentor teachers have a central role in shaping beginning teachers' beliefs and can significantly impact their learning (Cochran-Smith, 1991) the mentoring role as a conceptual model lacks clarity and the work of mentoring is considered to be complex and problematic (Harris, 1998; Rajuan, Beijaard, \& Verloop, 2010). Much earlier, Wheatley (1992) argued that roles and people are not fixed entities; they are relationships that involve one another and thus might operate within multiple identities which Hawkins (2005: p. 61) describes as a "dance in which identities are negotiated and constructed through social interaction”. Wenger (1998: p. 155) as well points out that identity is "work in progress" and "different ways of engaging in practice may reflect diffident forms of individuality, and different forms of accountability may call for different responses to the same circumstances". This notion is further supported by other studies which describe the dual roles of the mentor as a teacher of children and teacher of teachers (Korth el al., 2006; Tillema, Smith, \& Leshem, 2011); or as sometimes a novice and sometimes an expert, depending on contextual circumstances (Orland-Barak \& Yinon, 2005; Leshem, 2008).

Various schools of thoughts concerning the conceptualization of the role of the mentor point at diverse dimensions within the role. Definitions range from just "being there" (Feiman-Nemser, Parker, \& Zeichner, 1993) to offering "active assistance for student teachers" (Tomlinson, 1995) and to developing reflective professionals (Ballantyne, Packer, \& Hansford, 1995; Cochran-Smith \& Zeichner, 2006), who "think more broadly about their practice” (Fairbanks, Freedman, \& Kahn, 2000: p. 102).

Daloz (1986) refers to support and challenge as two dimensions of the mentoring role that could enhance or debilitate learning. He defines support as an affirming activity and challenge as generating dissonance and cognitive tension. He claims that when the relationship exhibits high support and low challenge, the students might feel comfortable and unthreatened but no development is prompted. When support is low and challenge is high the learner will feel intimidated and might withdraw completely. When support and challenge are low, the learner will be in a static state. When both support and challenge are high, learning and development will take place. The fact that mentors usually function in multiple roles and often are unable to meet the students' expectations causes tension in the mentor-student relationship (Bullough \& Draper, 2004). Cain (2009) believes that the ideal setting for a student is one that is welcoming, accepting and supportive.

Furlong et al. (1995) present three models of mentoring based on three different visions of the process of learning. They draw on O'Hear (1988) who advocates the apprenticeship model where learning is done through emulation of an experienced practitioner. From this perspective, to be a mentor is simply "to act as a model” (p. 179) offering practical tips, not requiring any particular skills. The competence model advocates a more systematic skill-based approach to learning to teach. The mentor is a trainer in the sense that pre-determined performance standards guide their mentoring. The reflective model is guided by Dewey's conception of teaching and learning which advocates enquiry into their own practice in order to reveal assumptions and theories that underlie their action (Dewey, 1933). Within this model mentors are more of "critical friends" needing the special skills to help students in the enquiry.

Furlong and Maynard (1995) argue that these models do not take into consideration the complexities of the developmental nature of learning. They claim that students go through different phases in their learning to teach and thus mentoring should also be developmental and undertake different roles at different stages of learning. It is recognized, for instance, that in the phase where students try to "fit in", they would take a pragmatic survival approach even if it conflicts with their ideas. At a later stage they would view the placement as an assessment task in which they have to adopt particular types of behaviour and will please the supervising tutor. This also aligns with Maynard and Furlong (2001) who found that trainees sometimes seek approval of their mentors and would avoid confrontation or relinquish individual teaching styles in order to create mentoring relationships of agreement (Rajuan, Beijaard, \& Verloop, 2010). This 
developmental notion seems to manifest mentoring as "a journey" (Awaya et al., 2003) and as "a process" of collaborative work (Kwan \& Tang, 1996; Lopez-Real \& Kwan, 2005). In light of this notion, Korthagen and Lagerwerf (1996) suggest different levels of conceptualization of the mentoring role that mentors might go through: they start with the Gestalt model, move through to the Schema model and then reach the Theory level.

Research also suggests that mentoring is culture-bound and mentors in different countries hold different beliefs about the nature of the mentoring (Wang, 2001). In the United States where a decentralized curriculum exists, mentors believed that what is important for student teachers to learn is how to cater for the individual; while in the more centralized systems like China, the primary concern is subject based teaching and developing understanding of curriculum and professional ethics. It could also be claimed that mentors do not have the autonomy to form their own conceptual model as teacher educators when university or colleges set institutional restrictions and define the boundaries and expectations for the mentor and the student (Zeichner, 1993; Arnold, 2006). Thus, it is still possible to accept Harris's (1998) view that the mentoring role as a conceptual model is quite ambiguous and context bound. These conceptual understandings guide the research analysis as it helps to illuminate the complexities of the mentor-mentee relationships.

\section{The Study}

\section{Context of Study}

The teacher education programme is an integrative four year programme in a teacher education college. Practice teaching occurs over consecutive years allowing for gradual immersion of student teachers into the school system and the task of teaching. Students start practice teaching in their second year of their BA/B.Ed/B.Sc studies. In their second year they are placed in PDS (Professional Development Schools) in multidisciplinary groups and spend one day a week in the school with a didactic supervisor from the institution and a mentor from the hosting school. In their third year students are placed individually into host schools with an experienced teacher in the student's discipline who is appointed as a mentor. Mentors are chosen by the school principal or pedagogical counselors in the school on the basis of experience. The mentors should have at least five years of teaching experience. Students and mentors are randomly matched and in most cases they do not know each other. If a student recommends a mentor and wishes to practice teach in a particular school, the mentor has to be approved by the college didactic lecturer. Occasionally, they are chosen due to circumstances of convenience such as proximity, or acquaintance.

\section{Participants}

The participants in the study were 15 pairs of mentors and their student teachers in different secondary schools. All mentors and their students were female except for one male mentor and one male student. Mentors' teaching experience ranged from five to 20 years. The student teachers were in their second year of practice teaching at a teacher education college. Students and mentors came from different disciplinary backgrounds ranging from social studies, sciences and humanities. Their ages ranged from 35 to 55 . All 15 pairs in the research were randomly matched by discipline. Participants were given pseudonyms.

\section{Design of Study}

The research design employs an inductive approach. The aim of the study was not to generalize to all mentors or student teachers, but to gain insights on the perceptions of the participants of this study on the role of the mentoring and the mentoring experience and to offer propositions to be advanced that other practitioners might wish to investigate in their own contexts. An open-ended questionnaire seemed to be the appropriate method for this research as it elicited lived experiences of the participants (Merriam, 1998).

The questionnaire of a common set of open questions was distributed electronically, by a research assistant to 25 pairs of student teachers and mentors. The sample comprises the 15 pairs who responded to the invitation to participate. The questionnaire was distributed separately to mentors and students so that they could each respond independently. Names or any identifiable details were removed to respect anonymity. The questionnaire consisted of eight open-ended questions to initiate written responses on topics that would capture the view of respondents in their own words on the role of the mentor and the mentoring relationships (see Appendix 1). The questions pertained to perspectives on "good teaching"; "good mentoring"; "role" of the mentor; assessment of performance in the mentoring process and assessment of collaboration (agreement/disagreement).

\section{Analysis}

Drawing on qualitative data analysis the data from the answers to the questionnaire items were systematically organized to facilitate the process of analyzing, interpreting and making meaning of the data (Bogdan \& Biklen, 1982). The approach to the data analysis involved the following: In order to obtain a holistic sense of the data (Creswell, 1998) and to identify similarities and differences of perceptions on the mentor's role, the responses to each question from mentors and students were organized in a table. Responses were read by two readers, the researcher and the research assistant, to determine common themes. Emergent themes were highlighted and then presented as descriptors for each question. Further verification and refinement of the descriptors entailed recursive processes of reading that yielded the formulation of categories pertaining to role perceptions (Patton, 1990). Table 1 lists the categories found for the mentors and students for each question. For example, "good teaching" was captured in a category of "personality traits", "student awareness" "professionalism” "reflection" and "education oriented". Conditions for "good mentoring" and the "role of the mentor" was captured in the categories of "teaching skills”, “modeling”, "guiding”, “collaboration, sharing” and "reflecting".

In order to identify the type of relationship within pairs of mentors and student teachers, written responses of the questionnaire for each pair were read again to identify words or phrases that related specifically to the nature of interaction, and to arrive at a synthesis of common grounded indicators for mentor mentee relationship. Examples of indicators for types of interaction were: openness, trust, sensitivity, availability, disagreement, compliance, mutual learning, sharing, respect. Peer review throughout the data analysis was used to ensure the credibility of the findings (Lincoln \& Guba, 1985). 
Table 1.

Categories of perceptions on mentoring.

\begin{tabular}{|c|c|c|}
\hline & Students' perceptions & Mentors' perceptions \\
\hline \multicolumn{3}{|l|}{ Good teaching } \\
\hline & Personality traits & Personality traits \\
\hline & $\begin{array}{l}\text { Interesting, raising curiosity; widening horizons, creative, } \\
\text { emotional. }\end{array}$ & Having a mission, challenging, empathic, sensitive, creative. \\
\hline & Student awareness & Student awareness \\
\hline & Leading to achievements, knowing pupils, building up identity. & $\begin{array}{l}\text { Empowering students, asking questions, creating positive } \\
\text { environment, catering for all. }\end{array}$ \\
\hline & Professionalism & Professionalism \\
\hline & Be a professional, transmit knowledge & $\begin{array}{c}\text { More than transmitting knowledge, expert of curriculum, } \\
\text { professional, educator }\end{array}$ \\
\hline & & Reflection \\
\hline & & $\begin{array}{l}\text { Teaching for self-thinking, independent thinking, to doubt and } \\
\text { be critical }\end{array}$ \\
\hline & Education oriented & \\
\hline & Community involvement, maintaining educational values & \\
\hline \multicolumn{3}{|l|}{ Good mentoring } \\
\hline & Teaching skills & Teaching skills \\
\hline & Help with preparing lessons, provide knowledge, skills & $\begin{array}{l}\text { Be expert, provide tools, skills, learn management, } \\
\text { connecting theory and practice }\end{array}$ \\
\hline & & Being a model \\
\hline & & Be a guide, the expert \\
\hline \multicolumn{3}{|c|}{ Guidance } \\
\hline & $\begin{array}{l}\text { Give constructive feedback, assistance, support, being } \\
\text { available, role model }\end{array}$ & \\
\hline & Collaboration & Collaboration and sharing \\
\hline & $\begin{array}{l}\text { Give feeling of confidence, show weak points, allow for } \\
\text { mistakes, strengthen identity, trust, dialogue }\end{array}$ & $\begin{array}{l}\text { Provide window, familiarize, share practice and } \\
\text { responsibility, socialize into school, interaction, learn from } \\
\text { each other, give space }\end{array}$ \\
\hline & & Reflection \\
\hline & & Space, objectivity, constructive \\
\hline \multirow[t]{4}{*}{$\begin{array}{l}\text { Process of mentoring } \\
\text { Benefits from } \\
\text { experience/contribution }\end{array}$} & $\begin{array}{l}\text { Learn to teach } \\
\text { Learn about children, theory, the role of the school, acquire } \\
\text { tool, link with reality of teaching }\end{array}$ & $\begin{array}{l}\text { Support } \\
\text { Give feedback, be role model, accept criticism, discuss and } \\
\text { have an open dialogue }\end{array}$ \\
\hline & Become teacher & Become teacher \\
\hline & Joy of doing, be interested, flexible, knowledgeable & Challenge with tasks and responsibility, to work hard \\
\hline & & Learn from students, connect theory with practice \\
\hline \multirow[t]{5}{*}{ Efforts invested } & Gain insights, advice, feedback, better lesson plans & \\
\hline & Process & Process \\
\hline & Good relations, create interest, invest effort, implement advice & Be accurate, willing to invest, go beyond, effort to prepare \\
\hline & & Product \\
\hline & & $\begin{array}{l}\text { Language use, manage class, catering learning styles, } \\
\text { knowing material, subject matter }\end{array}$ \\
\hline \multirow[t]{2}{*}{ assessment } & Interaction & Interaction \\
\hline & Solving disagreements, look for challenges & Accepting different views, criticism \\
\hline
\end{tabular}




\section{Findings}

\section{Role Perceptions: Similar or Different?}

A first holistic reading of the data identified emergent categories for perceptions on the role of mentoring (see Table 1). The findings reveal that perceptions are essentially similar but there are slight differences in orientations between students and mentors' perceptions.

Students in general are more concerned with the pragmatics, namely, micro classroom activities and teaching strategies. When they describe the benefits of mentoring they actually provide lists of teaching techniques that they have acquired: "knowing how to explain, making teaching material relevant to the pupils and raising curiosity through interesting and motivating ways of teaching." Mentors have a wider perspective of teaching and mentoring: "teachers need to be challenging, impart knowledge in motivating ways and perform as role models in all respects”.

Another theme which is dominant among the mentors is reflection as a critical component of good teaching and good mentoring (developing critical thinking, self-reflection, independent thinking). Students only allude to it. What stands out in both mentors' and students' texts is the acknowledgement of feedback sessions as crucial and a major source of knowledge about teaching. They also refer to it in their responses concerning the benefits of mentoring. However, the orientation here is again slightly different. Some mentors regard the feedback sessions as an "intellectual dialogue" as it stimulates them to reflect on their own practice; Students describe feedback as something that helps them develop the craft of teaching in their subject area as follows: "I gained some insights about how to organize my teaching materials." "I saw different ways of using visual aids to make the lesson more interesting." "I learned different ways of relating to pupils and how to build a good rapport with them."

A few students also mention benefits that transcend subject matter teaching techniques. For Dana (student) a lesson entails more than just teaching: "Every lesson, no matter what you teach, is an educational opportunity and it is important not to miss it." Lina (student) moves beyond the boundaries of the classroom and sees the interrelationship between the school community and the mentor-mentee relationship. "Good relationships between mentors and students depend much on how the school community welcomes us as learners in the school. It is not taken for granted."

\section{Student-Mentor Relationships}

The relational types that emerged from the analysis of patterns of relationships (Question 2) are as follows: an evolving relationship which indicates process; relationship of compliance which indicates agreement and acceptance, a learning relationship which indicates mutual learning, and a coaching relationship which indicates support and sensitivity. In the following section a selection of vignettes which portray the different typologies are illustrated.

\section{Evolving Relationship}

What characterizes the following cases is the developmental nature of the relationship as described by pairs of mentors and the students. Dafni (student) and Raya (mentor) describe a mentoring relationship which develops gradually into an agreement of acceptance. They learn in the course of the mentoring process to trust and accept differences of opinion. This is reflected in the following comment of Dafni. “Accepting feedback as constructive criticism is a process which has to be built on openness and trust. Along the way, we arrived at a sort of agreement that we are open to criticism”. Dafni's comment suggests that in order to reach such a position they first have to get to know each other to maintain an open and trustworthy relationship.

Mina's (student) description also captures the notion of time and process. She describes how with time she learns to accommodate to Rachel's style of teaching: "I realized that she was very particular about details and it was much against my view of things. It took me some time to appreciate her approach and see the rationale behind it".

\section{Learning Relationship}

Mary and Yana mentored by Sharon express quite explicitly that congruence of perspectives between mentors and students is crucial for good mentorship. Mary states quite directly the disadvantages of random pairing in spite of the fact that she is "lucky" having Sharon: "There must be mutual appreciation and congruence in educational perspectives between the mentor and the student. To my surprise the matching between mentor and student has been done on the basis of residence proximity. I expected it to entail a preceding meeting between the mentor and the student so that placement would be based on mutual agreement. Luckily, I was placed with a teacher who I learned from a lot and I admire her way of teaching and thinking, but I know colleagues who are placed with teachers from whom they learn what not to do or be."

Yana also thinks that the fact that she and Sharon share the same opinion on grades is a positive aspect of the practicum experience. “. ... the pleasant approach of the teacher and the fact that she is not grade oriented but stresses more progress and development, contributes a lot to the positive atmosphere and to the practicum experience.” Sharon, the mentor, remarks on the dialogical mode of mentoring and its two-way benefits: "I realized that the dialogue helped me and them to understand my pedagogical procedures. I felt that the conversations I had with the students improved my own teaching”. In her response to the question about the benefits of her mentoring to the students, she writes: "I hope I managed to communicate the great responsibility of educators and the need to continually ask questions about one's own practice. "Thus it seems that Mary Yana and Sharon have become a small community of learning. For them the congruence of perceptions has created a fertile ground for open conversations which benefited all of them.

Bath (mentor), for example, emphasizes the great responsebility in being a role model. She feels that she has to portray a positive image and thereby improve her own teaching: "I discovered that the open dialogue with the students assisted me as much as it assisted the students. The immense responsibility of being a model to look up to, and the need to convey the message that teaching is a mission, improved my own work as I felt I had to practice what I preach”. Hava is an experienced history teacher however, working with Ella, she admits that at times she feels insecure in the feedback sessions and recognizes that every student opens up new opportunities for learning. "I am sure the student benefited a lot from observing my lessons. Still, I feel I do not have enough experience in mentoring. I realize that I still have a lot to learn. Every student is a new world and I have to 
cope with different issues but this is how I am gaining experience."

\section{Relationship of Compliance}

Daniele teaches Bible and is Rosaline's mentor. They realize that they have different worldviews but decide somehow to resolve it. Rosaline writes: "It is problematic when there is a big gap between the mentor and the student concerning world views, especially when teaching the Bible. Every lesson I learn something new and it makes me think how I would do it." Daniele writes: "We decided that each teacher teaches according to their beliefs and we learned to respect each other's ways of thinking. It was a good lesson for me”. For Rosaline the dissonance of views creates a learning opportunity which prompts her to reflect on what she observes and gains insights on how she would teach it. Daniele prefers not to challenge the dissonance due to her respect for her mentor. Quite similarly, Limor appreciates the knowledge and experience of her mentor and prefers not to challenge her with questions albeit the fact that she does not always agree with her. At times I tended not to agree with things she was doing or saying, but she had a lot of experience and so much knowledge that I was reluctant to raise any questions and just took what I needed for my lessons.

Areen and Sima describe a similar conflict based on cultural differences. Areen, an Arab student chose to practice teach in a Jewish school having a Jewish mentor, Sima. This is quite exceptional as Arab students usually practice teach in Arab schools. Areen emphasizes the difficulty of "cultural gaps" and writes: "It was not easy to cope with the difficulties of a context I am not familiar with, but I respected my mentor's knowledge and accepted her views, although they were not always in line with my cultural values. Sima who acknowledges the difficulties she encounters, passively accepts her mentor's views out of respect to her knowledge. Areen, for whom this is also a unique experience, refers to it as a "learning opportunity" however; she too chooses not to further explore the cultural dissonance.

Some descriptions reflect implicit expectations that mentors and students have but they are not explicitly challenged. For example, Sara who is mentored by Lynn describes their relationship as "uneventful": "Our collaboration is smooth as the mentor usually does not do or say things that surprise me, thus there is no place for disagreement or elaborated discussion."

In other words, Sara needs something "surprising" to happen in order to challenge "discussion" or "disagreement" otherwise; she conforms to her mentor’s approach.

\section{Coaching Relationship}

Naama sees the role of the mentor as someone who is always there for her for everything she needs. She is very much dependent on her when preparing her lessons and takes her feedback very seriously. Mariana feels that her role is to encourage and help Naama in any and every way to succeed. She puts a lot of emphasis on the affective aspects of mentoring when she describes her role as a mentor. Orly describes a relationship that is based on patience and consideration. She writes: "My mentor is very considerate and always happy to help. She is very patient, guides me in whatever I need and always makes sure that everything is clear." Linda (student) articulates very clearly her expectations from her mentor. She seems to be at a stage where support is the most important thing she needs:

"What I need from my mentor most of all at this stage of my practice teaching is taking me by the hand. I am still not sure about anything I am doing or observing."

\section{Discussion and Conclusion}

The analysis of perceptions of mentors and students on what constitutes good mentoring and on their mentoring experience, reveals that there is no great dispute between the two groups and there are only slight differences in orientations as described in the findings. The patterns of relationships that have been identified portray a supportive ambience based on dialogue, usually with a tendency to agreement. Upon first reaction, the results should put us at ease, as it creates a learning environment which accords with Cain's ideal setting for a mentoring situation (Cain, 2009); and still, the complacent atmosphere is troublesome, especially, in light of the perceptual discrepancies echoed by Iris, Lisa and others.

Yet, another concern emerges from the incongruity between mentors" perceptions and their actual practice. Mentors (less so the students) consider reflection as one of the critical components in good mentoring. The expectations derived from such perceptions would be maintaining an inquiry oriented relationship; however, evidence shows that although there is "mutual learning", the orientations of the mentoring relationships are more of compliance and compromise. So how can we make sense of it?

Most students in the research are at their initial stages of practice teaching. They might have avoided taking risks and preferred taking the "safe zone" attitude. This aligns with the state of "novice" teachers who according to Berliner (2001) are intimidated by ambiguity and by dissonances caused by unfamiliar situations. Thus they are more oriented to self and tend to focus on their performance and their need to follow their mentor teachers (Huberman, 1993) like Dafni who sought to accommodate to here mentor"s style of teaching. Likewise, the benefits of mentoring noted by both students and mentors pertain mainly to practical aspects of teaching and rarely to wider educational aspects beyond "teaching tips" (although it has been alluded to by some students and mentors). This corresponds with students' needs of practical support and their adaptive stance to avoid challenges.

The findings also show that both the students and the mentors entered their respective roles having assumptions and expectations about teaching and mentoring. However, the students' encounter with the reality of teaching and the role hierarchy of mentor-student has an impact on their previously held perceptions. Some students relinquish their own views about teaching practices out of respect to the mentor's knowledge and experience. This is also shown in some of students' assertions that they "would do things differently when they become teachers". What is worrying is the fact that they identify dissonance, but they choose not to challenge it. They rather accommodate to the mentor's style of teaching and maintain a relationship of agreement (Rajuan, Beijaard, \& Verloop, 2010).

The evidence further suggests that mentors perform in emerging realities and embrace multiple roles and identities (Wheatley, 1992; Wenger, 1998; Hawkins, 2005) which influence the mentoring relationship and the learning process. They are the rolemodels to look up to and the masters of knowledge, guiding students how to perform. This would suggest an apprenticeship model (Maynard \& Furlong, 1993). They are also the coaches helping students to recognize their strengths and weaknesses and 
thus perform as critical friends. Yet, at times, they are learners themselves challenged by unanticipated situations which create opportunities for reflecting on their own practice, like Hava, the experienced history teacher who felt inexperienced in her role as a mentor and each student was a new experience for her. Thus a mentor's behavior may shift between a novice and an expert (Orland-Barak \& Yinon, 2005) seeking not to challenge the situations that they confront. The "novice state" might explain Lisa's voice and many others who feel that in order for learning to occur they would need a supportive mentoring context free of conflict.

The mentoring relationships also expose students and mentors to conflicting perceptions; however, they are not exploited as learning opportunities. This raises some critical questions: were students at different stages of learning where they could not yet articulate explorative questions and challenge their perceptions of classroom practices? Did they need different mentoring styles to accommodate to their personality and level of learning (Furlong, 1995)? Let's remind ourselves of Sara who felt that nothing surprising happened to stimulate a discussion or disagreement; was she at the novice stage, unable to recognize learning opportunities? Or, did she need a mentor who would challenge the discussion? In a study exploring the meanings that student teachers attribute to the experience of observation in the practicum Orland-Barak and Leshem (2009) found that consonant with their novice stage, students do not distinguish the surprising critical incidents as valued learning experiences. They propose the need to problematize and articulate insights from observation. Their findings might confirm Sara's situation. Going back to Iris and Lisa as illustrative cases, we could now assume that they were at different stages in their learning process and perhaps needed different mentoring orientations. This could explain the perceptual discrepancy that they describe. Thus, the proposition that could be advanced is that the mentoring relationship is developmental (Furlong \& Maynard, 1996) and does not follow a linear process. Mentors and students would need to adapt to situations that emerge. It confirms Jones” (2009) view that mentoring is contextualized and highly personalized.

What follows from the evidence is that mentors and students entered the mentoring experience with similar pedagogical beliefs. This created an accommodating and supporting context for learning. However, the harmonious relationship was mainly based on compliance. Although there is lack of agreement in the literature on whether similarities or differences of beliefs between mentors and students' yield better learning (Hobson et al., 2009) the evidence is somewhat disturbing and provokes food for thought. The main concern is that both mentors and students seemed to have missed opportunities for questioning beliefs and values of observed situations, which is a critical component of effective mentoring (Jones, 2009). Some of the explanations that have been provided above might well be the reason for the missed opportunities, and yet, the practical implications that I would like to suggest are that supportive contexts in the mentoring relationship should be a means to an end and not an end in itself. The harmonious relationship could provide the appropriate supporting context for students and mentors to exploit contradictions and conflicts as sites of inquiry (Graham, 1997; Tillema, 1995). The mentor-mentee relationship should be "upgraded". This could be achieved by interrogating systems of beliefs that underlie practice (Handal \& Lauvas, 1987; Hobson, 2009) and thereby bring about a theorized practice (Schon, 1987) where learning and development take place (Daloz, 1986).
Although this study is small in scale and its inductively produced findings cannot be generalized, it contributes to previous research and can inform teacher education in several ways: In the framework of most teacher education programmes students are assigned to schools and mentors without any preliminary systematic preparation for the mentoring experience. Likewise, in most cases mentors are chosen on the basis of years of experience and do not go through any training before undertaking their mentoring duties. The study highlights the complexities that mentorship entails. Consequently, more attention must be given to preparing students and mentors for their roles in the practicum. Although there is lack of evidence on the influence of mentor preparation on mentor effectiveness, some studies suggest that mentors are more likely to employ effective mentoring strategies where they have undertaken programmes of mentor preparation (Hobson, 2009). This might be achieved by offering workshops that will expose them to case studies and critical incidents in order to illuminate beliefs, expectations and dissonances, as points of departure for promoting reflective practice, and thereby acquire strategies to challenge students into deeper levels of thinking. Likewise, students will receive preparatory sessions prior to their practicum whereby they will be exposed to the different roles of the mentor and how they can raise their level of thinking by engaging in critical dialogue and challenge mentoring conversations.

In order to extend the insights of the present study I would encourage more research on the different learning processes which transpire within pairs of mentors and students at different phases in the mentoring process. The evidence might help identify the different needs of students and mentors and provide programme developers with more insights on how to enhance the level of learning in the mentoring experience.

\section{REFERENCES}

Arnold, E. (2006). Assessing the quality of mentoring: Sinking or learning to swim? ELT Journal, 60, 117-124. doi:10.1093/elt/cci098

Awaya, A., McEwan, H., Heyler, D., Linsky, S., Lum, D., \& Wakukawa, P. (2003). Mentoring as a journey. Teaching and Teacher Education, 19, 45-56. doi:10.1016/S0742-051X(02)00093-8

Ballantyne, R., Packer, J., \& Hansford, B. (1995). The crisis in teacher education: A European concern? London: Falmer Press.

Berliner, D. C. (2001). Learning about and learning from expert teachers. International Journal of Educational Research, 35, 463-482. doi:10.1016/S0883-0355(02)00004-6

Bogdan, R. C., \& Biklen, S. K. (1982). Qualitative research for education: An introduction to theory and methods. Boston: Allyn and Bacon.

Bullough, J. R, \& Draper, R. J. (2004). Mentoring and emotions. Journal of Education for Teaching, 30, 271-288. doi:10.1080/0260747042000309493

Cain, T. (2009). Mentoring trainee teachers: How can mentors use research? Mentoring and Tutoring: Partnership in Learning, 17, 53-66. doi:10.1080/13611260802233498

Cochran-Smith, M. (1991). Reinventing student teaching. Journal of Teacher Education, 42, 104-118. doi:10.1177/002248719104200204

Cochran-Smith, M., \& Zeichner, K. (2006). Studying teacher education. Washington DC: American Educational Research Association.

Creswell, J. W. (1998). Qualitative inquiry and research design: Choosing among five traditions. Thousand Oaks, CA: Sage Publications.

Daloz, L. (1986). Effective teaching and mentoring. San Francisco: Jossey-Bass.

Dewey, J. (1933). How we think: A restatement of the relation of reflective thinking in the educative process. Chicago: Henry Regnery. Eby, L. T., McManus, S. E., Simon, S. A., \& Russell, J. E. (2000). The 
protégé's perspective regarding negative mentoring experiences: The development of a taxonomy, Journal of Vocational Behavior, 57, 1-21. doi:10.1006/jvbe.1999.1726

Elliott, B., \& Calderhead, J. (1993). Mentoring for teacher development: Possibilities and caveats. In D. MdIntyre, H. Hagger, \& M. Wilkin (Eds.), Mentoring: Perspectives on school-based teacher education. London: Kogan Page.

Fairbanks, C. M., Freedman, D., \& Kahn, C. (2000). The role of effective mentors in learning to teach. Journal of Teacher Education, 51, 102-112. doi: $10.1177 / 002248710005100204$

Feiman-Nemser, S., Parker, M. B., \& Zeichner, K. (1993). Are mentor teachers teacher educators? In D. McIntyre et al. (Eds.), Mentoring. London: Kogan Page.

Furlong, J. \& Maynard, T. (1995). Mentoring student teachers: The growth of professional knowledge. London and New York: Routledge.

Graham, P. (1997). Tensions in the mentor teacher-student teacher relationship: Creating productive sites for learning within a high school English teacher education program. Teaching and Teacher Education, 13, 513-527. doi:10.1016/S0742-051X(96)00053-4

Handal, G., \& Lauvas P. (1987). Promoting reflective teaching: Supervision in practice. Milton Keynes: Open University Education Enterprises, 9-19.

Handy, C. (1999). Understanding organizations (4th ed.). Harmondsworth: Penguin Books.

Harris, B. M. (1998). Paradigms and parameters of supervision in education. In G. R. Firth, \& E. F. Pajak (Eds.), Handbook of research on school supervision. New York: Simon and Schuster Macmillan.

Hascher, T., Cocard, Y., \& Moser, P. (2004). Forget about theorypractice is all? Student teachers' learning in practicum. Teachers and Teaching: Theory and Practice, 10, 623-637.

Hawkey, K. (1997). Roles, responsibilities and relationships in mentoring: A literature review and agenda for research. Journal of Teacher Education, 48, 325-335. doi:10.1177/0022487197048005002

Hawkins, M. R. (2005). Becoming a student: Identity work and academic literacies in early schooling. TESOL Quarterly, 39, 59-82. doi: $10.2307 / 3588452$

He, Y. (2010). Strength-based mentoring in pre-service teacher education: A literature review. Mentoring and Tutoring: Partnership in learning, 17, 263-275.

Hiebert, J., Gallimore, R., \& Stigler, J. W. (2002). A knowledge base for the teaching profession: What would it look like and how can we get one? Educational Researcher, 31, 3-15. doi:10.3102/0013189X031005003

Hobson, A. J., Ashby, P., Malderez, A., \& Tomlinson, P. D. (2009). Mentoring beginning teachers: What we know and what we don't. Teaching and Teacher Education, 25, 207-216. doi:10.1016/j.tate.2008.09.001

Huberman, M. (1993). The lives of teachers. New York: Teachers College Press.

Iancu-Haddad D., \& Oplatka, I. (2009). Mentoring novice teachers: Motives, process and outcomes from the mentor's point of view. The New Educator, 5, 45-65. doi:10.1080/1547688X.2009.10399563

Jones, M. (2009). Supporting the supporters of novice teachers: An analysis of mentors' needs from twelve Europeancountries presented from an English perspective. Researchin comparative and International Education, 4, 4-21.

Korthagen, F. \& Lagerwerf, B. (1996). Reframing the relationship between teacher thinking and teacher behaviour: Levels of learning about teaching. Teachers and teaching: Theory and practice, 2, 161190.

Korth, B. B., Erickson, L., Hall, K. M., \& Martin, G. (2006). Defining teacher educator through the eyes of classroom teachers. The Meeting of the National Network for Education. Cincinnati.

Kwan, T. \& Tang, T. (1996). Learning experiences of overseas nonEnglish speaking background students: A case study of an Australian university. New Horizon in Education, 39, 90-95.

Leshem, S. (2008). Novices and veterans journeying into real-world teaching: How a veteran learns from novices. Teaching and Teacher Education, 24, 204-215. doi:10.1016/j.tate.2006.07.010
Lincoln, Y. S., \& Guba, E. G. (1985). Naturalistic inquiry. Thousand Oaks, CA: Sage Publications.

Lopez-Real, F., \& Kwan, T. (2005). Mentors’ perceptions of their own professional development during mentoring. Journal of Education for Teaching, 31, 15-24. doi:10.1080/02607470500043532

Merriam, S. (1998). Qualitative research and case study applications in education (2nd ed.). San Francisco: Jossey-Bass.

Maynard, T., \& Furlong, J. (1993). Learning to teach and models of mentoring. In D. McIntyre, H. Hagger, \& M. Wilkin (Eds.), Mentoring: Perspectives on school-based teacher education. London: Kogan Page.

Maynard, T., \& Furlong, J. (2001). The student teacher and the school community of practice: A consideration of "learning as participation". Cambridge Journal of Education, 31, 39-52. doi:10.1080/03057640123915

O’Hear, A. (1988). Who Teaches the Teachers? London: Social Affairs Unit.

Orland-Barak, L., \& Leshem, S. (2009). Observation in learning to teach: Forms of "seeing”. Teacher Education Quarterly, 36, 21-37.

Orland-Barak, L., \& Yinon, H. (2005). Sometimes a novice and sometimes an expert: Mentors' professional expertise as revealed through their stories of critical incidents. Oxford Review of Education, 31, 557-578.

Patton, M. Q. (1990). Qualitative evaluation and research methods (2nd ed.). Newbury Park, CA: Sage.

Rajuan, M., Beijaard, D., \& Verloop, N. (2007). The role of the cooperating teacher: Bridging the gap between the expectations of cooperating teachers and student teachers. Mentoring and Tutoring, 15, 223-242. doi:10.1080/13611260701201703

Rajuan, M., Beijaard, D., \& Verloop, N. (2010). The match and mismatch between expectations of student teachers and cooperating teachers: Exploring different opportunities for learning to teach in the mentor prelateships. Research Papers in Education, 25, 201-223. doi:10.1080/02671520802578402

Russell, M. I., \& Russell, J. A. (2011). Mentoring relationships: Cooperating teachers' perspectives on mentoring student interns. The Professional Educator, 35.

Schon, D. (1987). Education the reflective practitioner. San Francisco: Jossey-Bass.

Tillema, H. (1995). Changing the professional knowledge and beliefs of teachers: A training study. Learning and Instruction, 5, 291-318. doi:10.1016/0959-4752(95)00020-8

Tillema, H., Smith, K., \& Leshem, S. (2011). Dual roles conflicting purpose: A comparative study on perceptions on assessment in mentoring relations during practicum. European Journal of Teacher Education, 34, 139-159. doi:10.1080/02619768.2010.543672

Tomlinson, P. (1995). Understanding mentoring. Buckingham: Open University Press.

Tauer, S. M. (1998). The mentor-protégé relationship and its impact on the experienced teacher. Teacher and Teacher Education, 14, 205218. doi:10.1016/S0742-051X(97)00036-X

Wang, J. (2001). Contexts of mentoring and opportunities for learning to teach: A comparative study of mentoring practice. Teaching and Teacher Education, 7, 51-73. doi:10.1016/S0742-051X(00)00038-X

Wenger, E. (1998). Communities of practice: Learning, meaning and identity. New York: Cambridge University Press.

Wheatley, M. (1992). Leadership and the new science. San Francisco, CA: Berrett-Koehler.

Young, J. R., Bullough, R. V., Draper, R. J., Smith, L. K, \& Erickson, L. B. (2005). Novice teacher growth and personal models of mentoring: Choosing compassion over enquiry. Mentoring and Tutoring, 13, 169-188. doi:10.1080/13611260500105477

Zeichner, K. M. (1993). Designing educative practicum experiences for prospective teachers. The International Conference on Teacher Education, Tel-Aviv, 27 June-1 July.

Zeichner, K. M. (1996). Designing educative practicum experiences. In K. Zeichner, S. Melnick, \& M. L. Gomez (Eds.), Currents of reform in pre-service teacher education (pp. 215-234). New York: Teachers College Press, Columbia University. 


\section{S. LESHEM}

\section{Appendix 1: Questionnaire}

1) What is your understanding of "good teaching"?

2) How would you define the mentor's role during practice teaching?

3) What is your understanding of "good mentoring"?

4) How would you describe the mentoring you experienced in your practice teaching? Please support your response.

5) Can you list at least three things you feel you benefited from the mentoring?

6) How would you assess your effort during the practice period? What do you take into account?

7) How would you assess your performance during this practice period? What do you take into account?

8) To what extent did you experience agreement/disagreement in the mentoring process? 